IRSTI 89.57.45

A.K. Tolegen ${ }^{1}$, Zh.T. Omirzhanova ${ }^{2}$

( ${ }^{1,2}$ International Educational Corporation, Kazakh Leading Academy

of Architecture and Civil Engineering, Almaty, Republic of Kazakhstan)

\title{
THE PROBLEM OF FLOOD RISKS ALONG THE CROSS-BORDER RIVERS IN THE REPUBLIC OF KAZAKHSTAN
}

Annotation. In this article the authors consider the issues of flood risk along the Transboundary Rivers of the Republic of Kazakhstan. Floods significantly affect the ecological and socio-economic development of the country. It was found that traditional methods of collecting information about floods do not meet modern requirements and do not allow for prompt management decisions on flood prevention and response. The authors come to the conclusion that the most effective monitoring of floods and high waters is space monitoring. Due to the large frequency of observations and high efficiency of receiving and processing, satellite data are indispensable for solving problems of operational monitoring of the situation on rivers during the spring flood.

Key words: floods, risks, Transboundary Rivers, water supply, flood zones, emergency situation, monitoring, remote sensing of the earth, satellite images.

Floods are classified as dangerous hydrological risks. They are more or less periodically observed on most rivers in Kazakhstan and occupy one of the first places in a series of natural disasters in terms of damage to property and area of distribution. And in terms of the number of human victims and property damage, they occupy the second place after earthquakes [1].

A flood is an extensive inundation of water adjacent to a lake, river, or reservoir in an area that causes significant material damage and damage to public health. If the flooding is not accompanied by damage, it is a lake or river flood.

Currently, there are 1,345 flood-prone areas in Kazakhstan, which affect about 900 settlements and 56,555 objects, the area of possible flooding of which may amount to $45,570.997 \mathrm{~km}^{2}$. The most detailed flood-prone areas of Kazakhstan are shown in table 1 .

Table 1 - Flood-prone areas of the Republic of Kazakhstan by region

\begin{tabular}{|l|c|c|c|}
\hline \multicolumn{1}{|c|}{ Flood-prone areas } & Settlements & $\begin{array}{c}\text { Objects } \\
\text { (residential buildings) }\end{array}$ & Area, km sq. \\
\hline Atyrau region & 108 & 3241 & 20833 \\
\hline Akmola region & 86 & 235 & 62 \\
\hline The East Kazakhstan region & 157 & 15335 & 1019 \\
\hline Kyzylorda region & 51 & 16777 & 5973 \\
\hline West-Kazakhstan region & 95 & 215 & \\
\hline
\end{tabular}




\section{South Kazakhstan region}

29

504

2089

As shown in table 1 on the territory of Kazakhstan the most flood prone are 6 regions. Floods that occur in the Akmola, Atyrau, Kyzylorda and East Kazakhstan regions are associated with large flat rivers and are associated with prolonged spring floods.

In Kazakhstan, more than 300 floods of various origins have been registered in recent years, or rather ten years, of which $70 \%$ are floods associated with spring floods, $20 \%$ were caused by precipitation and $10 \%$ were caused by other causes [2].

Depending on the scale of flooding, there are: low, high, outstanding, catastrophic (table 2) [3].

In recent years, catastrophic floods on the Syrdarya, Ural and Irtysh rivers pose the greatest danger, the reasons for which, along with the impact of natural factors, can be factors associated with interstate relations: political and economic, water management, etc., as well as terrorist acts.

Table 2 - Classification of floods according to frequency of occurrence, size (magnitude) and composite damage

\begin{tabular}{|l|l|c|}
\hline \multicolumn{1}{|c|}{ Flood class } & \multicolumn{1}{|c|}{ Scale of distribution of flooding } & $\begin{array}{c}\text { Repeatability, } \\
\text { years }\end{array}$ \\
\hline Low (small) floods & $\begin{array}{l}\text { They cover small coastal areas and flood less than 10\% } \\
\text { of agricultural land located in low places. They cause } \\
\text { relatively minor damage and almost do not disrupt the } \\
\text { rhythm of life of the population. }\end{array}$ & $5-10$ \\
\hline A high flood & $\begin{array}{l}\text { They cover relatively large areas of river valleys and } \\
\text { flood approximately 10-15\% of agricultural land. They } \\
\text { cause significant material damage and significantly } \\
\text { disrupt the economic and everyday life of the population } \\
\text { and lead to partial evacuation of people and animals. }\end{array}$ & $20-25$ \\
\hline Outstanding floods & $\begin{array}{l}\text { They cover entire river basins, flood about 50 to 70\% of } \\
\text { agricultural land, and some localities. They cause great } \\
\text { material damage, paralyze economic activity and } \\
\text { dramatically disrupt the everyday way of life of the } \\
\text { population. Lead to mass evacuation of the population } \\
\text { and property from the flood zone. }\end{array}$ & $50-100$ \\
\hline Catastrophic floods & $\begin{array}{l}\text { They cover vast territories within one or several river } \\
\text { systems, flood more than 70\% of agricultural land, } \\
\text { many settlements. They cause colossal material } \\
\text { damage, completely paralyze economic and industrial } \\
\text { activities, lead to the death of people }\end{array}$ & $100-200$ \\
\hline
\end{tabular}


Under these conditions, the organization and conduct of effective ground-space monitoring of transboundary river basins, including the territory of neighboring states, significantly increases the level of national security of the state and strengthens the argumentation of the Kazakh side in the conduct of relevant international negotiations to resolve problems associated with catastrophic floods on transboundary rivers.

In Kazakhstan, transboundary rivers flow along the outskirts of the country. These include the rivers Irtysh, Ile, Syrdarya, Zhaiyk, Tobol, Esil and Shu. Due to the fact that these rivers are located on the outskirts of the country, therefore, more than $40 \%$ of water resources come from neighboring countries. In this regard, Kazakhstan is a water dependent country and the use of transboundary rivers is a very important problem for it. Therefore, a special place in the policy of the state is occupied by issues of interaction with neighboring countries on the joint use and protection of transboundary water resources [4].

Cross-border cooperation in flood risk management is not only necessary, but also useful. Early warning from upstream countries can save lives and reduce economic losses. In addition, collaboration helps to accumulate knowledge and build an information base, expanding the set of available strategies.

Water relations between the Republic of Kazakhstan and the People's Republic of China are regulated by the Agreement between the Government of the Republic of Kazakhstan and the Government of the People's Republic of China on cooperation in the use and protection of transboundary rivers (12.09.2001, Astana). In order to implement this Agreement, a Kazakh-Chinese Joint Commission on the Use and Protection of Transboundary Rivers, as well as a working group of experts, have been established [5].

Water relations with the Russian Federation are regulated by the Agreement «On the joint use and protection of transboundary water bodies» dated September 7, 2010.

In order to implement the agreement, a Kazakh-Russian commission for the joint use and protection of transboundary water bodies and 6 working groups on the protection and use of water resources of transboundary river basins have been established and are functioning: Zhaiyk, Ertis, Esil, Tobyl, Kigash, Karakzen and Saryuzen. The meetings of the commission are held at least 1 time, and the working groups are held at least 2 times a year, alternately in the territories of the parties.

Relations with the Republic of Kyrgyzstan on transboundary rivers are regulated on the basis of the Agreement between the Governments on the use of interstate water facilities on the Chu and Talas rivers dated January 21, 2000. Within the framework of the agreement, there is a commission of the Republic of Kazakhstan and the Kyrgyz Republic on the use of interstate water facilities on the Chu and Talas rivers.

Water relations with the neighboring states of the Amudarya and Syrdarya river basins are regulated by the Agreement between the Republic of Kazakhstan, the Republic of Kyrgyzstan, the Republic of Uzbekistan, the Republic of Tajikistan and Turkmenistan "On cooperation in the field of joint management of the use and protection of water resources of interstate sources») dated February 18, 1992. According to the norms of the above agreement, the Interstate Commission for Water 
Coordination of Central Asia and its executive bodies - the basin water associations «Syrdarya» and «Amudarya», operate in the region.

One of the priorities of the current stage of development of our country is to reduce one of the main risks - the risk of flooding, which over the past period of time has acquired a significant impact on the environmental and socio-economic development of the country.

The existing flood monitoring and forecasting system in Kazakhstan is based mainly on data from ground-based stationary observation points, whose network is extremely insufficient and has been reduced in recent years. The instrumentation at stations and posts is outdated, and the qualification of observers is not always high enough.

The methods used for assessing and predicting floods are not up-to-date and have long been in need of improvement using information on space remote sensing of the Earth's surface, the quality and resolution of which has increased over the past decade, while the cost has decreased. Therefore, the relevance of using space-based information for monitoring hydrometeorological emergencies, including floods, is not in doubt. Moreover, the use of space-based information will make it possible to switch from point-based flood risk assessments to area-based ones, which will significantly improve the reliability of planned measures to prevent natural emergencies.

Rapid assessment of the situation in the floodplain areas of major rivers of the country is necessary to prevent severe consequences of floods. Traditional methods of collecting information about floods do not meet modern requirements and do not allow you to quickly make management decisions on flood prevention and elimination of their consequences.

Timely receipt of the necessary information can ensure the use of satellite imagery data, which allows you to get the information you are interested in in a short time and ensure coverage of areas affected by floods.

Space monitoring of floods and floods has been carried out in Kazakhstan since 2002 in areas prone to flooding [6]. The main goals of space monitoring are:

- rapid detection of various emergencies on rivers, lakes, etc.;

- remote monitoring of the situation on rivers and lakes;

- assessment of existing emergencies;

- timely communication of the information received to the relevant responsible authorities and emergency situations at various levels.

Using flood monitoring, it is possible to study flood zones in a timely manner and with high accuracy and warn the population.

Remote sensing data can be used in flood research tasks at the following stages:

- early warning and flood forecasting for creating hydrological models;

- operational flood monitoring for flood monitoring and assessment;

- identification of affected areas to assess the consequences of flooding.

Due to the large frequency of observations and high efficiency of receiving and processing, satellite data are indispensable for solving problems of operational monitoring of the situation on rivers during the spring flood. They are particularly valuable in vast and inaccessible areas. 
To assess flooded areas, you can use satellite data from various systems (Landsat, SPOT, ERS), in order to create a «complete» set of data on the scale of flooding. For different sections, satellite data from different dates should be used to best match the product with the peak river flooding.

In modern conditions, the use of satellite data makes it possible to monitor and manage natural disasters such as floods, starting with the forecast, conducting operational monitoring and ending with the assessment of their consequences.

\section{References:}

1. Шарипханов С.Д., Раимбеков К.Ж., Кусаинов А.Б. Управление рисками наводнений. Методическое пособие /Кокшетауский технический институт КЧС МВД Республики Казахстан. - Кокшетау, 2015. - 94 с.

2. Бурлибаев М.Ж., Волчек А.А., Калинин М.Ю. Гидрологические стихийные явления (мировые тенденции, хроника Беларуси и Казахстана) //Водные ресурсы Центральной Азии и их использование, кн. 2: мат. междунар. научно-практ. конф., посв. подведению итогов объявленного ООН десятилетия «Вода для жизни». - Алматы, 2016. - С. 372-377.

3. Семенов В.А., Кобозева Г.Л., Коршунов А.А., Волков А.А., Шамин С.И. К вопросу создания информачионного обеспечения оценки климатически обусловленных изменений повторяемости опасных и неблагоприятных гидрологических явлений на реках// Труды ВНИИГМИИ-МЦД. - 2010. - Вып. 174.

4. Бердыгулова Г.Е. Современное состояние трансграничных рек Казахстана и проблемы их совместного использования. - Алматьи, 2014.

5. Юридический сборник Казахстанско-Китайское трансграничное водное сотрудничество. - Ташкент, 2015.

6. Spivak L.F., Arkhipkin O.P., Sagatdinova G.N. Development of Flood Monitoring Information System in Kazakhstan //Proceedings of 31st International Symposium on Remote Sensing of Environment. - Saint-Petersburg, 2005.

В данной статье авторами рассматриваются вопросы возникновения риска наводнений вдоль трансграничных рек Республики Казахстан. Наводнения значительно влияют на экологическое и сочиально-экономическое развитие страны. Было установлено, что традиционные методы сбора информации о наводнениях не отвечают современным требованиям и не позволяют оперативно принимать управляющие решения по предупреждению наводнений и ликвидации их последствий. Авторы приходят к выводу, что наиболее эффрективным мониторингом наводнений и паводков является космический мониторинг. Благодаря большой периодичности наблюдений и высокой оперативности получения и обработки, спутниковые данные незаменимы при решении задач оперативного мониторинга обстановки на реках в период весеннего половодья.

Ключевые слова: наводнения, риски, трансграничные реки, водообеспеченность, зоны затопления, чрезвычайная ситуация, мониторинг, дистанционное зондирование земли, космические снимки.

Бұл мақ̧алада авторлар Қазақсстан Республикасының трансшекаралық өзендерінің бойында су тасқ̧ыны қ̧аупінің туындауы мәселелерін қ̧арастырады. Су тасқ̧ыны елдің 
экологияльқ және әлеуметтік-экономикалық дамуына айтарлықтай әсер етеді. Су тасқьыны тураль ақпарат жинаудың дәстүрлі әдістері қзазіргі заманвы талаптарва сәйкес келмейтіндігі және су тасқынының алдын алу және олардың салдарын жою бойынша басқ̧арушы шешімдерді жедел қ̧абылдаува мүмкіндік бермейтіні анықталды. Авторлар су тасқынын мен оның ең тиімді мониторингі гарыштық мониторинг болып табылады деген қъорытындыва келді. Бақылаудың үлкен жиілігі мен ққабылдау мен өңдеудің жовары тиімділігінің арқасында спутниктік мәліметтер көктемгі су тасқыыны кезінде өзендердегі жавдайды жедел бақылау мәселелерін шешуге таптырмас әдіс больп табылады.

Түйін сөздер: су тасқыны, тәуекелдер, трансшекаралық өзендер, сумен құамтамасыз ету, су басу аймақттары, төтенше жавдай, мониторинг, жерді қ̧ашықтықта зондтау, гарыштық түсірілімдер. 